\title{
An investigation of the influence of entrepreneurial orientation on the perceived success of agribusinesses in South Africa
}

\author{
H.M. Lotz ${ }^{*}$ and S.P. van der Merwe \\ Potchefstroom Business School, North-West University, \\ Private Bag X6001, Potchefstroom 2520, Republic of South Africa \\ henry.lotz@nwu.ac.za and stephan.vandermerwe@nwu.ac.za
}

\begin{abstract}
The objective of this study was to investigate the influence of an entrepreneurial orientation on the perceived success of agribusinesses in South Africa. Business success, for the purpose of this study, was measured by means of two dependent variables, namely Business development and improvement and Business growth. Structured questionnaires were administered to managers in five of the largest and three smaller agribusinesses in South Africa. In total, 533 usable questionnaires were returned. Construct validity of the measuring instrument was assessed by means of a principal component exploratory factor analysis and by calculating Cronbach alpha coefficients. The results show that the managers in the participating agribusinesses perceived that the entrepreneurial orientation factors of Proactiveness, Risk-taking and Autonomy have a positive influence on their business development and improvement. A positive relationship was also found to exist between the entrepreneurial orientation factors of Proactiveness, Autonomy and Innovativeness and the dependent variable Business growth in the participating businesses. To enhance the entrepreneurial orientation in agribusiness, it is recommended that the word "entrepreneurship" should specifically be included in the vision statement of the business, setting goals and developing strategies for entrepreneurship. The focus of the business then becomes opportunity identification, discovery of new sources of value, and product and process innovation that could lead to greater success.
\end{abstract}

*To whom all correspondence should be addressed.

\section{Introduction}

As a result of fast-changing technologies, ever-increasing changes in customer demand and the growing levels of intense global competition (Ireland \& Webb, 2009: 1), today's business environment is marked by continuous change. Within this new competitive situation, Drejer (2006: 143) is of the opinion that the key competitive success factor will be the ability of a business to continuously develop new products, processes or services, providing consumers with increased functionality and performance. Consequently, businesses that are not continually innovative may be making the unintentional strategic decision to be out of business within a few years (Ramachandran, Devaranjan \& Ray, 2006: 86).

In this regard, an entrepreneurial orientation represents the processes, practices and decision-making activities that lead to the development and delivery of new innovative products, services and processes (Chang, Lin, Chang \& Chen, 2007: 999) and is consistently suggested in the literature as a key for success to higher performance (Yamada \& Eshima, 2009: 1). Three dimensions of entrepreneurial orientation, namely Innovativeness, Proactiveness and Risk-taking have been identified and used consistently in the literature (Rauch, Wiklund, Lumpkin \& Frese, 2009:763) based on the earlier research of Miller (1983). For the purpose of this study, two additional dimensions of entrepreneurial orientation, namely Autonomy and Competitive aggressiveness have been included, as viewed by Lumpkin and Dess (1996) to be critical to the entrepreneurial orientation concept.

Agribusinesses play an important role in the development of a country's agricultural sector as suppliers of farming requisites, marketers of agricultural commodities and providing services such as storage and transport (Ortmann \& King, 2007: 62). The many challenges that agribusinesses in South Africa face, include policy reforms, increasing global competition, a changing social environment and complex consumer demand (Doyer, D'Haese, Kirsten \& Van Rooyen, 2007: 495). These challenges demand that decision-makers effectively manage uncertainty and their business' resources to position their business in ways that will allow it to adapt to these changes and challenges. An entrepreneurial orientation may provide a tool for agribusiness development, revenue growth, enhanced profitability and pioneering the development of new products, services and processes that could lead to a sustained competitive advantage (Baran \& Velickaité, 2008: 22).

\section{Problem statement and objective}

Empirical studies support the proposition that there is a positive relationship between entrepreneurial orientation and business performance, meaning in practice that businesses that adopt a more entrepreneurial orientation perform better 
(Madsen, 2007: 188). However, several studies show that this effect is context-specific (Covin \& Slevin, 1989; Wiklund \& Shepherd, 2005) and may also vary according to national culture (Knight, 1997; Rauch, Wiklund, Frese \& Lumpkin, 2004).

Although the body of knowledge concerning the relationship between a business' entrepreneurial orientation and its performance is growing, it is still an under-explored topic (Covin, Green \& Slevin, 2006: 58) with most research being conducted within the United States of America (Frank, Kessler \& Fink, 2010: 175). Within the South African context, limited research of this nature has been conducted and specifically none among agribusinesses. Against this background, the objective of this research is to investigate the relationship between the entrepreneurial orientation of agribusinesses in South Africa and their perceived success.

\section{Operationalisation of variables}

Entrepreneurial orientation has its roots in the strategymaking process literature and represents the policies and practices that provide the basis for entrepreneurial decisions and actions (Rauch et al., 2009: 763). Based on Miller's (1983: 770) conceptualisation that an entrepreneurial business is one that engages in product market innovation, undertakes somewhat risky ventures and is first to come up with proactive innovations, three dimensions of entrepreneurial orientation were identified, namely Innovativeness, Risk taking and Proactiveness. Covin and Slevin (1989: 76) further refined Miller's definition by stating that the entrepreneurial orientation of a business is demonstrated by the extent to which the top managers are inclined to take business-related risks (risk-taking dimension), to favour change and innovation in order to obtain a competitive advantage for their business (innovative dimension), and to compete aggressively with other businesses (proactive dimension). While a number of authors have adopted similar definitions, for example Zahra, Jennings and Kuratko (1999: 50), and Morris, Kuratko and Covin (2008: 54), many others have made subtle changes that altered the meaning of the construct (George \& Marino, 2011:992). For example, Dess and Lumpkin (2005:147) define entrepreneurial orientation as the strategy-making practices that businesses use to identify and launch corporate ventures. This definition is clearly limited to decisions related to the launch of new ventures. Therefore, a business may have a high entrepreneurial orientation based on the Covin and Slevin (1989) definition, but not necessarily on the Dess and Lumpkin (2005) definition.

Furthermore, authors have defined the domain of entrepreneurial orientation as containing fewer or more dimensions (George \& Marino, 2011: 992). Two other dimensions were added by Lumpkin and Dess (1996: 139140), namely Competitive aggressiveness and Autonomy. These authors argue that entrepreneurial orientation includes a propensity to act autonomously and a tendency to be aggressive towards competitors. Wang (2008:637), on the other hand, adopted four dimensions, namely proactiveness, competitive aggressiveness, risk-taking and innovativeness. Another contentious issue has been the two principle ways in which the entrepreneurial orientation construct has been conceptualised as a uni-dimensional construct or a multidimensional construct. Earlier studies viewed entrepreneurial orientation to be a uni-dimensional construct (Miller 1983; Covin \& Slevin, 1989), meaning that the exhibition of only one or two of the dimensions would be insufficient to label the business as entrepreneurial (Covin \& Lumpkin, 2011: 862). Later research (Lumpkin \& Dess, 1996; Wiklund \& Shepherd, 2005; Casillas \& Moreno, 2010) suggested that entrepreneurial orientation be considered a multi-dimensional construct that exists as a set of independent dimensions. According to George and Marino (2011: 1000), this implies that entrepreneurial orientation is created by its dimensions, rather than the dimensions being manifestations of entrepreneurial orientation.

Although the entrepreneurial orientation construct has been widely debated (Covin \& Lumpkin, 2011: 855), there is unfortunately no consensus on matters such as an appropriate definition of the construct, its domain or its dimensionality (Covin \& Lumpkin, 2011: 856; George \& Marino, 2011: 992). For the purpose of this study, it is our belief that entrepreneurial orientation refers to a business' strategic orientation, one which captures the specific entrepreneurial aspects of decision-making styles, methods and practices. We further view the entrepreneurial orientation construct as consisting of five independent dimensions, namely autonomy, innovativeness, risk-taking, proactiveness and competitive aggressiveness.

Many conceptual arguments from previous research, especially those that view entrepreneurial orientation as a one-dimensional construct, have found a positive relationship between the single variable entrepreneurial orientation and business performance (Dess, Lumpkin \& Covin, 1997; Wiklund \& Shepherd, 2005). In contrast, Frank et al. (2010) found a positive relationship between entrepreneurial orientation and business performance only in cases in which a dynamic environment exists and found a negative relationship in cases where a stable environment exists.

Those who view entrepreneurial orientation as a multidimensional construct have found that not all the dimensions influence business performance the same way. Casillas and Morena (2010) found significant positive relationships between the dimensions proactiveness and innovativeness with business growth. However, no relationships were found between risk-taking and competitive aggressiveness with business growth, respectively. Autonomy and growth were also not significantly related. Although not significantly, Lumpkin, Brigham and Moss (2010) found positive relationships between long-term business performance and all five dimensions of entrepreneurial orientation, with risk-taking and competitive aggressiveness the least positive.

Therefore, there are many different findings in the literature concerning the influence of entrepreneurial orientation on business performance; not only in general, but in particular situations (Miller, 2011:878). 
In Figure 1 (the hypothesised model), the dimensions of entrepreneurial orientation hypothesised as influencing the dependent variable, Perceived success of the organisation, are depicted, namely Autonomy, Innovativeness, Risk-taking, Proactiveness and Competitive aggressiveness. The model proposes that the dimensions of entrepreneurial orientation investigated in this study positively influence the Perceived success of the organisation.
The dimensions of an entrepreneurial orientation investigated in this study (see Figure 1) are justified by a sufficiency of theory in corporate entrepreneurship literature, and claims are not made that the model has an exhaustive coverage of every possible factor influencing the Perceived success of the organisation.

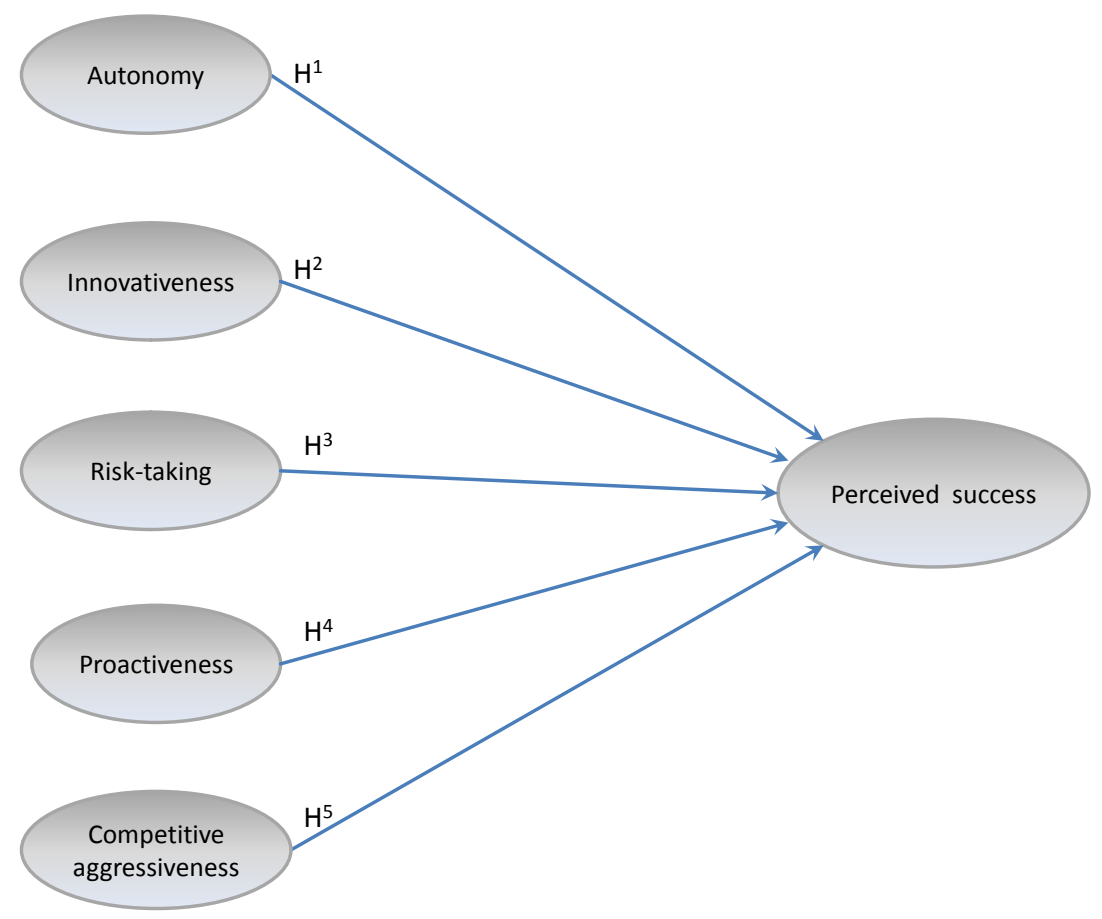

Figure 1: The hypothesised model

\section{Dependent variables}

There is general agreement in the literature that performance is a multidimensional concept (Lumpkin \& Dess, 1996: 137; Madsen, 2007: 195; Rauch et al., 2009: 765) and that multiple performance measures must be used rather than a single dimension. Unfortunately, there is no consensus on the appropriate measures of performance (Wiklund, 1999: 39) and the literature supports a high variety of performance measures (Madsen, 2007: 195). Performance may therefore depend upon the indicators used to assess performance. A common distinction is often made between financial and non-financial performance measures (Rauch et al., 2009: 765).

Financial measures, according to Van der Post (1997: 75), provide a solid foundation from which to draw inferences regarding the success and effectiveness of an organisation, because all efforts and systems are eventually aimed at ensuring sustainable financial returns. The most popular financial measures have included sales growth (Covin \& Slevin, 1991; Covin, Green \& Slevin, 2006; Frank et al., 2010; Madsen, 2007; Richard, Wu \& Chadwick, 2009; Wiklund \& Shepherd, 2005), growth in profits (Wiklund \& Shepherd, 2005), growth in cash flow (Frank et al., 2010; Wiklund \& Shepherd, 2005), return on assets (Covin \&
Slevin, 1991; Richard et al., 2009) and growth in market share (Madsen, 2007).

Non-financial measures have included growth in employment (Gürbüz \& Aykol, 2009; Madsen, 2007; Wiklund \& Shepherd, 2005), new product/service/process (Lee \& Sukoco, 2007; Wiklund \& Shepherd, 2003) and customer satisfaction (Wiklund \& Shepherd, 2003), among others.

Having an entrepreneurial orientation implies, among others, that a commitment to innovation must be at the heart of the strategic management process (Kuratko \& Audretsch, 2009: 3). In this regard, Collis and Montgomery (2005: 33) argue that a consistent flow of expenditure needs to be directed to innovation in order to ensure acceptable longterm levels of strategic intellectual stock that can ensure a sustainable competitive advantage to a successful firm. Terminating innovation efforts during bad times (Christensen, Johnson \& Rigby, 2002: 22) may have the consequences that promising initiatives are cut off and probably worst of all is that it creates a scepticism about and resistance to any future innovation initiatives (Wolpert, 2002: 78).

A measure of business success is often related to the effectiveness and efficiency that a business' employees are 
able to employ in producing the business' outputs (Dess, Ireland, Zahra, Floyd, Janney \& Lane, 2003: 370). In this regard, Kuratko and Audretsch (2009: 9) state that innovations can significantly increase the efficiency or effectiveness of businesses. Effectiveness is seen as "doing things right" in order to create value for the business, while efficiency relates to "doing the right things" in order to ensure the maximum output while expending the minimum input (Jacobs, Chase \& Aquilino, 2009: 6).

Finally, successful businesses create people-centred businesses in which human capital is viewed as the most important asset (Kreitner \& Kinicki). The intrinsic and extrinsic rewards flowing from a culture of corporate entrepreneurship strongly drive both organisational commitment and job satisfaction among employees (Bulut \& Alpkan, 2006: 67). Furthermore, committed and satisfied employees may also have a positive effect on the entrepreneurial orientation of the business, since Hayton (2005: 22) is of the opinion that employees are regarded as a determining factor, even imperative, in developing an entrepreneurial orientation.

For the purpose of this study, the dependent variable Perceived success will be measured by using the following items: whether employees are viewed as the most valuable asset of the business; whether employees are highly committed to the business; whether the morale (job satisfaction) of employees has improved over the past few years; whether the image (stature) of the business, relative to competitors, has grown over the past few years; whether the effectiveness (doing the right things) of the business has improved over the past few years; whether, during difficult economic periods, investments in research and development/innovative projects continue with no significant financial cuts; whether the efficiency (doing things right) of the business has improved over the past few years; whether the business has experienced growth in profits over the past few years; whether the business has experienced growth in turnover over the past few years; whether the business has experienced growth in market share over the past few years; and whether the competitive position of the business has improved over the past few years.

\section{Independent variables}

Among the different conceptualisations of entrepreneurial orientation, three dimensions of entrepreneurial orientation Innovativeness, Risk-taking and Proactiveness - have been suggested, adopted and extensively used in other studies (Covin \& Slevin, 1989; Wiklund \& Shepherd, 2005; Morris et al., 2008; Gürbüz \& Aykol, 2009; Richard et al., 2009; Frank et al., 2010). Two other dimensions, namely Autonomy and Competitive aggressiveness, have also been considered important in measuring entrepreneurial orientation (Lumpkin \& Dess, 1996; Dess \& Lumpkin, 2005; Covin et al., 2006). For the purpose of this study, these five dimensions will be considered as independent variables influencing the dependent variable, Perceived success of the agribusinesses and will be discussed in this section.

\section{Autonomy}

Autonomy refers to the independent actions of an individual or a team in bringing forth an idea or a vision and carrying it through to completion (Lumpkin \& Dess, 1996: 140; Lee \& Sukoco, 2007: 551).

To encourage autonomy, business uses both "top-down" and "bottom-up" approaches. The top-down approach includes aspects such as management support for programmes, giving incentives that foster a climate of entrepreneurship and welcoming autonomous decision-making (Dess \& Lumpkin, 2005: 149). In this regard, Dess et al. (2003: 355) are of the opinion that such business design features may be as important to entrepreneurial success as the other dimensions of an entrepreneurial orientation. To encourage autonomy from the bottom up will require special incentives and structural arrangements designed to develop and build support for entrepreneurial initiatives (Lumpkin, Cogliser \& Schneider, 2009: 49).

Furthermore, many businesses have engaged in actions such as flattening hierarchies and delegating authority to operating units. While these moves are intended to foster autonomy, the process of business autonomy requires much more than a change in design. Businesses must actually grant autonomy and individuals must be encouraged to exercise it (Mumford, Scott, Gaddis \& Stange, 2002: 724).

Although Lumpkin and Dess proposed the inclusion of Autonomy as a dimension of entrepreneurial orientation in 1996 , very few studies have investigated autonomy as an element of entrepreneurial orientation (Lumpkin et al., 2009:48). Consequently, the relationship between Autonomy and Business success has not been debated. Autonomy, however, constitutes one of the bases for innovative and entrepreneurial behaviour (Casillas \& Morena, 2010: 270) and businesses that rely on an entrepreneurial orientation to create new value and grow must encourage entrepreneurial behaviour by allowing employees to act and think more independently (Gürbüz \& Aykol, 2009:324). Autonomy is therefore essential to the process of leveraging a business' existing strengths, identifying opportunities and encouraging the development of new ventures and/or improved business practices (Lassen, Gertsen \& Riis, 2006: 361). Prior research (Rauch et al., 2009; Brock, 2003) also supports the view that autonomy encourages innovation, promotes the launching of new ventures and increases the competitiveness and effectiveness of businesses. Therefore, considering the above arguments, we propose the following hypothesis:

$\mathrm{H}^{1}$ : There is a positive relationship between Autonomy in the workplace and the Perceived success of the participating agribusinesses.

\section{Innovativeness}

The importance of innovation to entrepreneurship was first emphasised by Lumpkin and Dess (1996: 141), who proposed that innovation is the single dimension that has to be employed by all entrepreneurial businesses. It can therefore be argued that, even in the presence of the other dimensions, if innovation is not employed there is no 
business level entrepreneurship (Gürbüz \& Aykol, 2009: 323). Innovativeness reflects a business' tendency to engage in and support new ideas, novelty, experimentation and creative processes that may result in new products, services or processes (McFadzean, O’Loughlin \& Shaw, 2005: 353). Product/service innovation presents any change in the product or service range that a business takes to market and has proved to be potentially significant sources of strategic advantage (Cooper, 1998: 499). Product/service innovation is the most clearly understood form of innovation and consists of disruptive (or radical) innovation and incremental innovation (Schilling, 2005: 38).

Many definitions have been proposed for radical innovation and incremental innovation, but most of the definitions hinge on the degree to which an innovation represents a departure from existing practices (Schilling, 2005: 43). Process innovation is any change in the way a product/service is created or delivered (Johnson, 2001: 139) and these innovations are usually invisible to the user except for changes in the cost or quality of the product. By making a product better or cheaper, disrupted upstream or downstream linkages may not be necessary (Anderson \& Tushman, 2004: 38). Similar to product innovation, process innovation can either be disruptive or incremental. Most process innovations are incremental improvements that result in incremental improvements in key performance parameters, for example cost reduction, quality enhancement and time reduction. Disruptive process innovations are radical shifts to new process routes for the business and perhaps, for the industry as well (Bessant, 2003: 5).

The relationship between Innovativeness and firm performance presents the greatest degree of consensus (Casillas \& Moreno, 2010:269) with most studies finding a positive relationship. For example, Rauch et al. (2009); Morena and Casillas (2008); Subramanian and Nilakanta (1996) and Kleinschmidt and Cooper (1991) all found a positive relationship between Innovativeness and Business performance and growth. As a result, there is a growing recognition that innovation has become the only sustainable source of growth, competitive advantage and new wealth (Drejer, 2006:143). According to Wiklund and Shepherd (2003:1309), innovative businesses can generate extraordinary performance and have been described as the engines of economic growth. We are therefore confident that a positive relationship between innovativeness and perceived success exists and propose the following hypothesis:

$\mathrm{H}^{2}$ : There is a positive relationship between the Innovativeness and the Perceived success of the participating agribusinesses.

\section{Risk-taking}

The term risk is defined by Dewett (2004: 258) as the extent to which there is uncertainty about whether potentially significant and/or disappointing outcomes of a decision will be realised. In this regard, Mullins and Forlani (2005: 51) characterise risk as either the potential to act too quickly on an unsubstantiated opportunity (sinking the boat) or the potential to wait too long before acting (missing the boat).

Risk is inherent in the operations of any business and almost every decision taken by managers involves risk (Von Stamm, 2008: 387). Often, corporate entrepreneurial businesses that have an entrepreneurial orientation are typified by risk-taking behaviour, such as incurring heavy debt or making large resource commitments, in the interest of obtaining high returns by exploiting opportunities in the marketplace (Bhardwaj, Agrawal \& Momyaya, 2007: 134). However, this risk does not refer to extreme or uncontrollable risk, but rather to moderate and calculated risk (Morris et al., 2008: 62). Corporate entrepreneurs are therefore not high risk-takers (Lambing \& Kuehl, 2007: 19). Instead, they try to define the risk they have to take, minimise it as much as possible and manage it (Timmons \& Spinelli, 2009: 52). These enterprises should rather be viewed as risk-aware and opportunity-focused (McBeth \& Rimac, 2004: 18).

Another aspect of risk-taking is the assumption, which is often made, that innovativeness and risk-taking are directly correlated, that is, doing more innovative things means taking higher risks. According to Morris et al. (2008: 62), this relationship is far more complex. Risk is also high when business ignores new product/service opportunities and engages in little or no innovation. In this regard, Burns (2008: 291) notes that while not innovating presents a minimal risk in the short term, it does create a high risk in the long term. In essence, businesses that do not innovate are faced with a higher risk of not perceiving market and technology shifts that are capitalised on by competitors. The opposite is also true. Businesses that attempt to come up with breakthrough innovations that create new markets and redefine industries also face high risk (Morris et al., 2008: $63)$.

To be successful in future, businesses will need to exploit an entrepreneurial orientation with the ability to rapidly sense, act and mobilise under highly risky conditions (McGrath \& MacMillan, 2000: xiv), given factors such as globalisation, deregulation, technological and social change as well as information technology that are forcing businesses to cope with rapid and unexpected change, which has long been central to the theory of entrepreneurship (Shane, Locke \& Collins, 2003: 264).

The relationship between risk-taking and the success of a firm is not so clear (Rauch et al., 2009) and Wiklund and Shepherd, (2005: 75) argue that there is research that suggests that while tried-and-true strategies may lead to high performance, risky strategies may lead to performance variation since some projects fail while others succeed. Against this background, the following hypothesis is subjected to further testing:

$\mathrm{H}^{3}$ : There is a positive relationship between the Risk-taking propensity and the Perceived success of the participating agribusinesses. 


\section{Proactiveness}

According to Madsen (2007: 187), Proactiveness refers to a posture of anticipating and acting on future wants and needs in the marketplace, thereby creating a first-mover advantage vis-à-vis competitors. As first movers, businesses can control access to markets by dominating distribution channels, charge high prices and "skim" the market ahead of competitors (Wiklund \& Shepherd, 2005: 75), secure access to rare resources, gain new knowledge of key factors and issues, carve out market share and be in a position that is easy to defend and costly for rivals to overtake (David, 2007: 200). First movers are, however, not always successful. The introduction of novel products or breakthrough technologies is not always accepted by the market. Therefore, careful analysis of the environment and extensive feasibility research are needed for a proactive strategy to lead to a competitive advantage (Dess \& Lumpkin, 2005: 151).

Lumpkin and Dess (1996: 146), however, argue that although the idea of acting in anticipation of future demand is an important component of entrepreneurship, the idea of being first to the market is somewhat narrowly construed. A business can be novel, forward thinking and fast without always being first. Subsequently, Lumpkin and Dess (1996: 146) suggest that Proactiveness refers to processes aimed at anticipating and acting on future needs by seeking new opportunities that may or may not be related to the present line of operations and the introduction of new products and brands ahead of competition. Some of the activities that are therefore associated with proactiveness include new opportunity identification and evaluation, identification and monitoring of market trends and new venture team formation (Kropp, Lindsay \& Shoham, 2008: 104). A proactive business is therefore a leader rather than a follower, since it has the will and the foresight to seize new opportunities, even if it is not always the first to do so (Gürbüz \& Aykol, 2009: 323).

Apart from Innovativeness, Rauch et al. (2009) found that Proactiveness is the other integrating dimension of entrepreneurial orientation that offers a more intense positive relationship with business performance. Casillas and Moreno (2010) also found that proactive businesses reveal greater performance and growth. Therefore, we are in favour of defending a positive relationship between a business' proactiveness and its success:

$\mathrm{H}^{4}$ : There is a positive relationship between the Proactiveness and the Perceived success of the participating agribusinesses.

\section{Competitive aggressiveness}

Competitive aggressiveness refers to a business' propensity to directly and intensely challenge its competitors (Lumpkin \& Dess, 1996: 148) in an attempt improve position in the market place (Chang et al., 2007: 1000). It is important to note that within the context of entrepreneurial orientation, Competitive aggressiveness is a reaction to competitive trends and demands that already exist in the marketplace
(Lumpkin \& Dess, 2001:434). It therefore translates to a response to threats from competitors.

Businesses that are competitively aggressive are characterised by responsiveness, which may take the form of head-to-head confrontation, for example when a business enters a market that another competitor has identified (Lee \& Sukoco, 2007: 550). Responsiveness may also take the form of a business being reactive, for example when a business lowers prices in response to a competitive challenge. Furthermore, Competitive aggressiveness also reflects a willingness to be unconventional rather than relying on traditional methods of competing. This includes, among others, adopting unconventional tactics to challenge industry leaders, analysing and targeting a competitor's weakness and focussing on high value-added products (Lumpkin \& Dess, 2001: 434).

Although closely related, Lumpkin and Dess (1996: 147) feel that there is an important distinction between Competitive aggressiveness and Proactiveness that needs to be clarified. Proactiveness refers to how a business relates to market opportunities by seizing initiative and acting opportunistically in order to shape the environment, that is, to influence trends and perhaps even create demand. In contrast, Competitive aggressiveness refers to how businesses relate to competitors, that is, how businesses respond to trends and demand that already exist in the marketplace.

Competitive aggressiveness has generally been investigated less frequently (Lumpkin \& Dess, 2001:431), we believe for two reasons. Firstly, similar to Autonomy, Competitive aggressiveness has not been part of the "original" dimensions of entrepreneurial orientation and secondly, prior theory and research have often treated Proactiveness and Competitive aggressiveness as if they were interchangeable (Lumpkin \& Dess, 2001:431). Competitive aggressive behaviour is, however, less related to a strategy oriented to growth, since Casillas and Moreno (2010:284) argue that it is a reactive behaviour to competitors or behaviour in defence of a market position. Consistent with their view, they found no relationship between competitive aggressiveness and growth.

The following hypothesis is therefore subjected to further testing:

$\mathrm{H}^{5}$ : There is a positive relationship between the Competitive aggressiveness and the Perceived success of the participating agribusinesses.

\section{Research methodology}

\section{Research approach}

The research approach followed in this study was quantitative in nature, since quantitative research is used to answer questions about relationships among measured variables with the purpose of explaining, predicting and controlling phenomena (Leedy \& Omrod, 2005: 94-95). 
Primary data was collected by means of structured questionnaires and analysed by conducting an exploratory factor analysis and multiple linear regression. The research approach is deemed appropriate for gaining information to answer the overall research question and against which the hypotheses could be tested.

\section{Research method}

The research method will be discussed in the following sections, namely measuring instrument, research participants, research procedure and statistical analysis.

\section{Measuring instrument}

The dimensions of entrepreneurial orientation investigated in this study, namely Autonomy, Innovativeness, Risktaking, Proactiveness and Competitive aggressiveness were identified in the literature (Morris et al., 2008: 54; Covin \& Slevin, 1989: 76; Lumpkin \& Dess, 1996: 139-140; Zahra et al., 1999: 50). Items measuring the dimensions were compiled based on the following measuring instruments, namely The corporate entrepreneurship climate instrument (Morris et al., 2008), Entrepreneurial climate (Oosthuizen, 2006), Measuring intrapreneurship (Hill, 2003), Corporate entrepreneurship assessment instrument (Hornsby, Kuratko \& Zahra, 2002), Intrapreneurship items (Antoncic \& Hisrich, 2001), Entrepreneurial orientation items (Lumpkin \& Dess, 2001), The organisation structure and strategic posture scale (Covin \& Slevin, 1989) and Entrescale (Knight, 1997).

Respondents were requested to indicate their extent of agreement with each statement posed by means of a fivepoint Likert scale (where 1 indicates they strongly disagree and 5 that they strongly agree with the statement).

A section of the measuring instrument included the gathering of biographical information for possible future correlations with the opinions expressed in the survey. Respondents were requested to indicate their age group, gender, race, managerial level, highest academic qualification and division they worked in according to predefined categories.

\section{Research participants}

The study population for this study consisted of two populations. The first study population consisted of agribusinesses in South Africa and the second, managers within those agribusinesses. The first study population was selected by means of a non-probability sampling technique, namely judgement sampling, where the sample was selected based on the judgement of the researcher (Zikmund \& Babin, 2007: 412). Five of the largest agribusinesses (in terms of group turnover and group assets) and three of the smaller agribusinesses were included in the study.

The second study population consisted of all the managers (senior, middle and junior levels) within these agribusinesses. No sampling technique was therefore required. With the assistance of the Human Resource Managers in each of the agribusinesses, management levels were identified by means of the particular job grading system used by that specific agribusiness. A list of all the managers was provided by the Human Resource Manager for each of the participating agribusinesses.

\section{Research procedure}

The questionnaires were mailed or personally delivered to a designated person (in most instances the Human Resource Manager) in a specific agribusiness, who acted as a contact person and also assisted with the distribution and subsequent collection of the questionnaires. Respondents were requested to anonymously and voluntarily complete the questionnaire and return the completed forms to the designated person. In total, 1792 questionnaires were distributed from which 533 usable questionnaires were returned - representing a response rate of $29,74 \%$.

\section{Statistical analysis}

The data was firstly subjected to an exploratory factor analysis to assess the construct validity of the measuring instrument. This was followed by calculating the Cronbach alpha coefficients to assess the reliability of the measuring instrument. Finally, the relationships between the independent and dependent variables were examined by means of multiple linear regression analysis. The above analyses were done making use of Statistica (Statsoft, 2010) and PASW Statistics (PASW, 2010).

\section{Results and discussion}

\section{Demographic information}

Most of the participating managers in this study were between the ages 30 to 39 years old $(32,5 \%)$, followed by the second highest group $(31,2 \%)$ with ages between 50 to 59 years old and the third highest group $(25,5 \%)$ with ages between 40 and 49 years old. Together, these three groups account for $89 \%$ of the total respondents. Males constituted approximately $84 \%$ of the respondents. A total of $53 \%$ of respondents represented lower-level management, with middle and higher management levels represented by $34 \%$ and $11 \%$ respectively.

\section{Construct validity of measuring instrument}

The dangers of using scales not validated for a specific country context have been highlighted in the international business literature (Antoncic \& Hisrich, 2001; Knight, 1997: 215; Scheepers, Bloom \& Hough, 2008: 2). For example, Kemelgor (2002) concluded that entrepreneurial orientation is characterised by cultural differences. Even though the domain of entrepreneurial orientation has received a substantial amount of theoretical and empirical attention (Rauch et al., 2009: 762), the vast majority of publications has been from American authors (Frank et al., 2010: 175).

In order to conduct the exploratory factor analysis, the data was divided into two models. The first model related to the dependant variable, whereas the second model related to the independent variables. In identifying the factors to extract 
for each model, the percentage of variance explained and the individual factor loadings were considered.

With regard to the first model concerning the dependent variable, an Oblimin oblique rotation was performed on the principal components of the exploratory factor analysis, since there was theoretical justification to believe that the factors measuring perceived success would correlate with each other (Field, 2009: 643). Two tests, namely Bartlett's test of sphericity and the Kaiser-Meyer-Olkin measure of sampling adequacy were considered important in determining the appropriateness of the data for factor analysis (Gürbüz \& Aykol, 2009: 327). The data measuring the perceived success yielded a sampling adequacy of 0,863 and the Bartlett's test of sphericity yielded a $p$-value of smaller than 0,0001 , indicating that patterns of correlations are compact and that factor analysis should yield reliable factors (Field, 2009: 647).

To determine the number of factors to be extracted, Kaiser's criterion was used, namely to retain factors with eigenvalues greater than one (Field, 2009: 647). All of the 11 items demonstrated sufficient discriminant validity by loading to a sufficient extent. Factor loadings greater than 0,35 were considered significant (Field, 2009: 637; Stevens, 1992: 382-384). The factor matrix of the 11 items is provided in Table 1.

Table 1: Oblimin rotated factor matrix: Dependent variable ${ }^{(1)}$

\begin{tabular}{|c|c|c|}
\hline Item $^{(2)}$ & $\begin{array}{c}\text { Factor 1: Business development and } \\
\text { improvement }\end{array}$ & $\begin{array}{c}\text { Factor 2: } \\
\text { Business growth }\end{array}$ \\
\hline Success 7 & 0,801 & 0,161 \\
\hline Success 9 & 0,791 & 0,008 \\
\hline Success 8 & 0,714 & 0,064 \\
\hline Success 10 & 0,510 & $-0,361$ \\
\hline Success 5 & 0,471 & $-0,334$ \\
\hline Success 11 & 0,449 & $-0,017$ \\
\hline Success 6 & 0,382 & $-0,352$ \\
\hline Success 2 & $-0,067$ & $-0,848$ \\
\hline Success 1 & $-0,151$ & $-0,846$ \\
\hline Success 3 & 0,213 & $-0,610$ \\
\hline Success 4 & 0,397 & $-0,418$ \\
\hline Cronbach Alpha & 0,812 & 0,731 \\
\hline
\end{tabular}

(1) Loadings greater than 0,35 were considered significant

(2) The items included in the factor analysis are provided in Appendix 1

Table 1 shows that the items expected to measure Perceived success split into two separate factors that were named Business development and improvement and Business growth. Three items loaded significantly onto both the factors (values greater than 0,35). Rather than deleting the items, it was decided to classify them under the factor that has the highest loading. The correlation matrix for the two dependent variables indicated a correlation of 0,569 between the variables (Ellis \& Steyn, 2003: 53), confirming that an oblique rotation should have been used (Field, 2009: 643).

For this study, Business development and improvement refers to highly committed employees viewed as the most valuable asset of the business and the improvement of job satisfaction, image of the business, efficiency and effectiveness over the past few years with continued investments in research and development/innovative projects even during difficult economic periods. Business growth refers to growth in profits, turnover, market share and the competitive position of the business over the past few years.

To assess the discriminant validity of the 27 items measuring the entrepreneurial orientation of managers in agribusinesses, an exploratory factor analysis was conducted. Two tests, namely Bartlett's test of sphericity and the Kaiser-Meyer-Olkin measure of sampling adequacy were considered important in determining the appropriateness of the data for factor analysis (Gürbüz \& Aykol, 2009: 327). The data measuring the entrepreneurial orientation yielded a sampling adequacy of 0,897 and the Bartlett's test of sphericity yielded a p-value of smaller than 0,001 , indicating that patterns of correlations are compact and that factor analysis should yield reliable factors (Field, 2009: 647).

An Oblimin oblique rotation was performed on the principal components of the exploratory factor analysis. To determine the number of factors to be extracted, Kaiser's criterion was 
used, namely to retain factors with eigen-values greater than one (Field, 2009: 647). A total of 24 items demonstrated sufficient discriminant validity by loading to a sufficient extent. The loadings of three items (Innovative9, Proactive1 and Competitive4) were not significant (below the value of $0,35)$ and were therefore deleted. The factor matrix of the remaining 24 items is provided in Table 2.

Applying the factor extraction criterion that the eigen-values must be greater than one (Davis, 2005: 446), five factors were extracted in the exploratory factor analysis explaining $53,15 \%$ of the variance before rotation. After rotation, these factors could be identified as the theoretical dimensions of Proactiveness, Autonomy, Risk-taking, Innovativeness and Competitive aggressiveness.

Factor one, labelled Proactiveness, consisted of eight items. Two items (Proactive3; Proactive4) that were used to measure the latent variable Proactiveness loaded onto factor one. Five items (Innovative7, Innovative2, Innovative4, Innovative8, Innovative6) relating to the latent variable Innovativeness, were also included in factor one. One item (Risk3), used to measure the latent variable Risk-taking, was also included in factor one. These items were regarded by respondents as being related to the factor Proactiveness. For the purpose of this study, Proactiveness refers to the continuous monitoring of market trends and future needs of customers, opportunities created by these trends and needs are pursued, existing products/services are continuously improving and new product/services are continually provided.

The second factor, labelled Autonomy, comprised four items. Four of the five items that were originally intended to measure the latent variable Autonomy (Autonomy4, Autonomy1, Autonomy2; Autonomy5) loaded onto the factor Autonomy, as expected. One item loaded significantly onto two factors (values greater than 0,35). The item Autonomy5 loaded onto both the factors Autonomy and Risk-taking. Rather than deleting the item, it was decided to classify it under the factor that has the highest interpretation value, namely Autonomy. Autonomy refers to employees being encouraged to manage their own work without continual supervision and being allowed flexibility to be creative and try different methods to do their jobs.

Table 2: Oblimin rotated factor matrix: Independent variables ${ }^{(1)}$

\begin{tabular}{|c|c|c|c|c|c|}
\hline Item $^{(2)}$ & $\begin{array}{c}\text { Factor 1: } \\
\text { Proactiveness }\end{array}$ & $\begin{array}{l}\text { Factor 2: } \\
\text { Autonomy }\end{array}$ & $\begin{array}{l}\text { Factor 3: } \\
\text { Risk-taking }\end{array}$ & $\begin{array}{l}\text { Factor 4: } \\
\text { Innovativeness }\end{array}$ & $\begin{array}{c}\text { Factor 5: } \\
\text { Competitive } \\
\text { aggressiveness }\end{array}$ \\
\hline Proactive4 & 0,763 & $-0,056$ & 0,108 & $-0,023$ & 0,020 \\
\hline Innovative7 & 0,761 & $-0,020$ & 0,091 & 0,008 & $-0,026$ \\
\hline Proactive3 & 0,719 & $-0,066$ & 0,041 & 0,232 & $-0,022$ \\
\hline Innovative 2 & 0,647 & 0,030 & 0,083 & 0,146 & 0,020 \\
\hline Innovative4 & 0,630 & 0,008 & 0,037 & 0,170 & 0,079 \\
\hline Innovative8 & 0,590 & 0,143 & 0,016 & 0,003 & $-0,007$ \\
\hline Risk3 & 0,544 & 0,063 & $-0,181$ & $-0,066$ & 0,121 \\
\hline Innovative6 & 0,457 & 0,080 & 0,220 & 0,085 & 0,006 \\
\hline Autonomy4 & 0,141 & 0,768 & $-0,064$ & $-0,028$ & 0,094 \\
\hline Autonomy1 & $-0,079$ & 0,762 & $-0,067$ & 0,083 & 0,008 \\
\hline Autonomy2 & 0,199 & 0,700 & 0,038 & 0,034 & $-0,060$ \\
\hline Autonomy5 & $-0,159$ & 0,414 & 0,367 & 0,113 & 0,049 \\
\hline Risk2 & 0,000 & $-0,283$ & 0,764 & 0,154 & 0,065 \\
\hline Risk5 & 0,160 & 0,043 & 0,634 & $-0,011$ & 0,108 \\
\hline Risk4 & 0,204 & 0,222 & 0,523 & $-0,217$ & 0,009 \\
\hline Autonomy3 & $-0,044$ & 0,306 & $\mathbf{0 , 5 0 7}$ & $-0,080$ & $-0,060$ \\
\hline Risk1 & 0,061 & $-0,035$ & 0,466 & 0,043 & 0,073 \\
\hline Innovative3 & $-0,039$ & 0,083 & $-0,103$ & $\mathbf{0 , 8 8 2}$ & 0,007 \\
\hline Innovative1 & 0,277 & $-0,044$ & $-0,049$ & 0,711 & $-0,018$ \\
\hline Innovative5 & 0,029 & 0,091 & 0,175 & 0,581 & 0,050 \\
\hline Competitive1 & $-0,223$ & $-0,014$ & 0,031 & $-0,005$ & 0,912 \\
\hline Competitive3 & 0,315 & 0,086 & 0,001 & $-0,005$ & 0,504 \\
\hline Competitive2 & 0,295 & $-0,017$ & 0,094 & 0,121 & 0,497 \\
\hline Proactive2 & 0,311 & 0,030 & 0,053 & 0,005 & 0,445 \\
\hline Cronbach alpha & 0,855 & 0,676 & 0,647 & 0,678 & 0,672 \\
\hline
\end{tabular}

(1) Loadings greater than 0,35 were considered significant

(2) The items included in the factor analysis are provided in Appendix 1 
The third factor, which comprised five items, was labelled Risk-taking. Four items (Risk2, Risk5, Risk4; Risk1), that were originally used to measure the latent variable, Risktaking, loaded onto this factor as expected. One item (Autonomy3), measuring the latent variable Autonomy, also loaded onto the Risk-taking factor. In this study, Risk-taking refers to the business having a strong inclination towards high risk projects and when confronted with uncertainty, the business typically adopts a bold posture to maximise the probability of exploiting opportunities. Furthermore, the term 'risk-taker' is considered a positive attribute for employees and consequently employees are encouraged to take calculated risks concerning new ideas without going through elaborate justification and approval procedures.

Factor four consisted of three items and was labelled Innovativeness. All three items (Innovative3, Innovative1, Innovative5) that were originally intended to measure the latent variable, Innovativeness, loaded onto the factor as expected. For the purpose of this study, Innovativeness refers to the regular introduction of new products/services/processes, the increase in the number of service/product offerings during the past two years and the extent to which these new products/services/processes have been dramatic within the past few years.

Factor five, labelled Competitive aggressiveness, consisted of four items. Three items (Competitive1, Competitive3; Competitive2) that were used to measure the latent variable Competitive aggressiveness loaded onto factor five. One item (Proactive2), used to measure the latent variable Proactiveness, was also included, being regarded by respondents as also being related to Competitive aggressiveness. In this regard, Competitive aggressiveness refers to when an aggressive posture is assumed not only against competitors, but also any industry trends that may compromise survival or competitive position.

The wording of the statements (items) originally measuring the five latent variables is provided in Appendix 1. The exploratory factor analysis, together with the interpretability of the factors, provides some evidence of construct validity.

Reliability of measuring instrument

To assess the internal consistency of the items measuring the various factors under investigation, Cronbach alpha coefficients were calculated (Bryman \& Bell, 2007: 164). Coefficient alpha measures internal consistency by computing the average of all split-half reliabilities for a multiple-item scale (Zikmund \& Babin, 2007: 322). The coefficient varies between 0 for no reliability, and 1 for maximum reliability (Kent, 2007: 142) and values of below 0,7 can realistically be expected with psychological constructs (Field, 2009: 668). Since this study is an exploratory assessment of managerial perceptions in agribusinesses in South Africa, a value of 0,6 is acceptable, although 0,7 is preferred to indicate a higher level of reliability (Bagozzi, 1994: 18). The results in Table 1 and Table 2 suggest that the proposed instrument is reliable with no factors below the Cronbach alpha value of 0,6 .

\section{Modified hypotheses}

As a result of the exploratory factor analysis, it was deemed necessary to reformulate the original hypotheses depicted in the hypothesised model (Figure 1). These relationships are summarised below:

$\mathrm{H}^{1 \mathrm{a}}$ : There is a positive relationship between Autonomy in the workplace and Business development and improvement of the participating organisations

$\mathrm{H}^{1 \mathrm{~b}}$ : There is a positive relationship between Autonomy in the workplace and the Business growth of the participating organisations

$\mathrm{H}^{2 \mathrm{a}}$ : There is a positive relationship between Innovativeness in the organisation and Business development and improvement

$\mathrm{H}^{2 \mathrm{~b}}$ : There is a positive relationship between Innovativeness in the organisation and the Business growth of the participating organisations

$\mathrm{H}^{3 \mathrm{a}}$ : There is a positive relationship between the Risk-taking propensity in the organisation and Business development and improvement

$\mathrm{H}^{3 \mathrm{~b}}$ : There is a positive relationship between the Risk-taking propensity in the organisation and the Business Growth of the participating organisations

$\mathrm{H}^{4 \mathrm{a}}$ : There is a positive relationship between Proactiveness in the organisation and Business development and improvement

$\mathrm{H}^{4 \mathrm{~b}}$ : There is a positive relationship between Proactiveness in the organisation and the Business growth of the participating organisations

$\mathrm{H}^{5 \mathrm{a}}$ : There is a positive relationship between Competitive aggressiveness in the organisation and Business development and improvement

$\mathrm{H}^{5 \mathrm{~b}}$ : There is a positive relationship between Competitive aggressiveness in the organisation and the Business growth of the participating organisations

The modified hypothesised model is illustrated in Figure 2. 


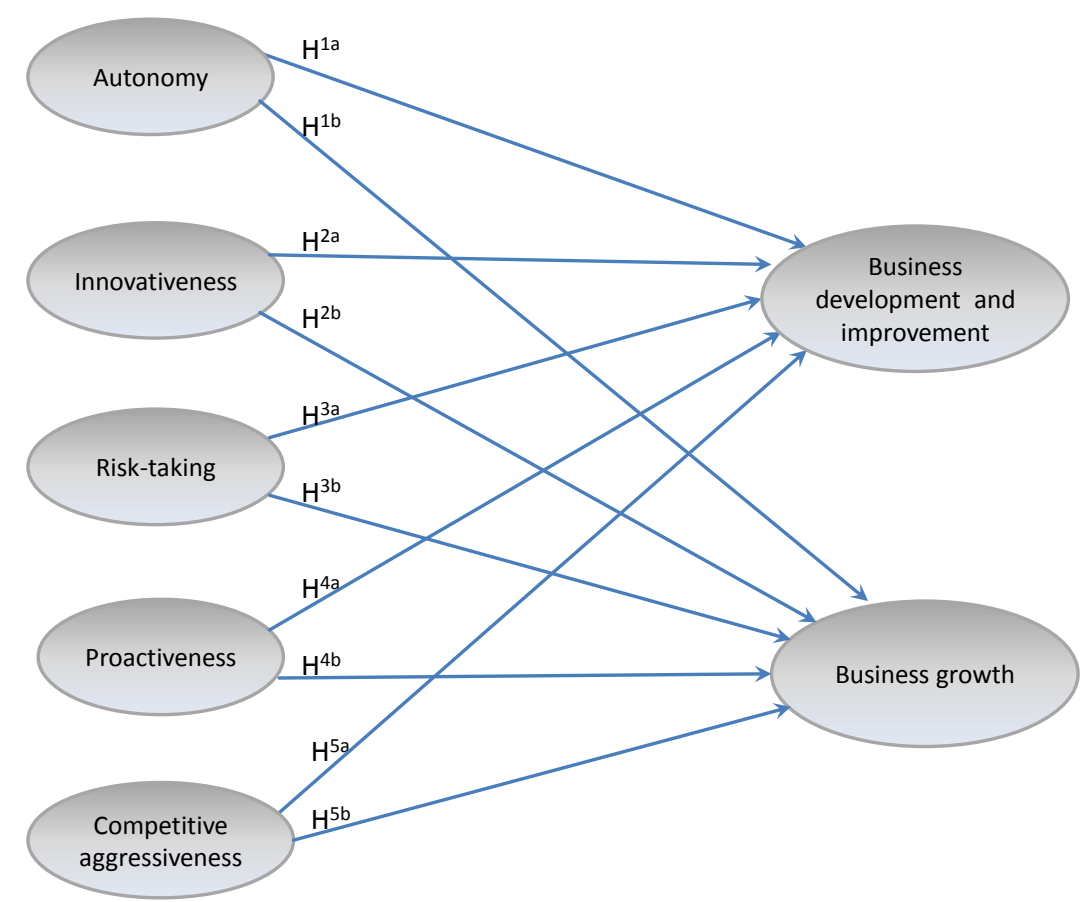

Figure 2: The modified hypothesised model

\section{Multiple regression analyses results}

In order to determine whether the independent variables Proactiveness, Risk-taking, Autonomy, Innovativeness and Competitive aggressiveness - have an influence on the dependent variables Business development and improvement and Business growth, a multiple regression analysis was performed. Factor scores for each participant were computed as the average of all items contributing to the relevant factor, automatically replacing missing values by means of substitution. The results of the multiple regression analysis for the influence of the independent variables on the dependent variables are presented in Tables 3 and 4, respectively. A normal probability plot on the residuals of this fit confirmed the assumption of normality.

Table 3 indicates that, in practice, a significant percentage $(53,1 \%)$ of the variation in the Business development and improvement of the participating organisations is explained by the five entrepreneurial orientation variables, i.e.
Proactiveness, Risk-taking, Autonomy, Innovativeness and Competitive aggressiveness.

The multiple regression analysis indicates significant positive relationships between the independent variables Proactiveness ( $p<0,001)$, Risk-taking $(p=0,022)$ and Autonomy $(\mathrm{p}<0,001)$ and the dependent variable Business development and improvement, respectively. No significant relationship could be found between the independent variables Innovativeness and Competitive aggressiveness and Business development and improvement.

The hypotheses that there is a positive relationship between the variables Proactiveness $\left(\mathrm{H}^{4 \mathrm{a}}\right)$, Risk-taking $\left(\mathrm{H}^{3 \mathrm{a}}\right)$ and Autonomy $\left(\mathrm{H}^{1 \mathrm{a}}\right)$ and Business development and improvement respectively were therefore accepted. The hypotheses that there is a positive relationship between the independent variables Innovativeness $\left(\mathrm{H}^{2 \mathrm{a}}\right)$ and Competitive aggressiveness $\left(\mathrm{H}^{5 \mathrm{a}}\right)$ and Business development and improvement were, however, not accepted.

Table 3: Multiple regression results: Impact of the independent variables on the dependent variable Business development and improvement

\begin{tabular}{|c|c|c|c|c|c|}
\hline \multirow[b]{2}{*}{ Model } & \multicolumn{2}{|c|}{ Non-standardised coefficients } & \multirow{2}{*}{$\begin{array}{c}\begin{array}{c}\text { Standardised } \\
\text { coefficients }\end{array} \\
\text { Beta } \\
\end{array}$} & \multirow[b]{2}{*}{ t-value } & \multirow[b]{2}{*}{ p-level } \\
\hline & B & Std. Error & & & \\
\hline (Constant) & 0,453 & 0,138 & & 3,280 & 0,001 \\
\hline Proactiveness & 0,470 & 0,044 & 0,453 & 10,776 & $0,000^{* *}$ \\
\hline Risk-taking & 0,073 & 0,032 & 0,082 & 2,296 & $0,022 * *$ \\
\hline Autonomy & 0,234 & 0,029 & 0,271 & 8,105 & $0,000^{* *}$ \\
\hline Innovativeness & 0,083 & 0,066 & 0,080 & 1,260 & 0,208 \\
\hline Competitive aggressiveness & 0,036 & 0,052 & 0,041 & 0,703 & 0,482 \\
\hline
\end{tabular}

$\mathrm{R}^{2}=0,531(* * \mathrm{p}<0,05)$ 


\begin{tabular}{|c|c|c|c|c|c|}
\hline \multirow[b]{2}{*}{ Model } & \multicolumn{2}{|c|}{ Non-standardised coefficients } & \multirow{2}{*}{$\begin{array}{c}\text { Standardised } \\
\text { coefficients }\end{array}$} & \multirow[b]{2}{*}{ t-value } & \multirow[b]{2}{*}{ p-level } \\
\hline & B & Std. Error & & & \\
\hline (Constant) & 1,916 & 0,152 & & 12,582 & 0,000 \\
\hline Proactiveness & 0,327 & 0,048 & 0,339 & 6,804 & $0,000 * *$ \\
\hline Risk-taking & $-0,079$ & 0,035 & $-0,095$ & $-2,238$ & $0,026^{* *}$ \\
\hline Autonomy & 0,080 & 0,032 & 0,100 & 2,511 & $0,012 * *$ \\
\hline Innovativeness & 0,274 & 0,073 & 0,282 & 3,763 & $0,000 * *$ \\
\hline Competitive aggressiveness & 0,016 & 0,057 & 0,019 & 0,272 & 0,785 \\
\hline
\end{tabular}

$\mathrm{R}^{2}=0,34 * *(\mathrm{p}<0,05)$

Table 4 indicates that, in practice, a significant percentage $(34,0 \%)$ of the variation in Business growth is explained by five entrepreneurial orientation variables, i.e. Proactiveness, Risk-taking, Autonomy, Innovativeness and Competitive aggressiveness.

The multiple regression analysis indicates significant positive relationships between the independent variables Proactiveness ( $p<0,001)$, Autonomy $(p=0,012)$ and Innovativeness ( $p<0,001)$, and the dependent variable Business growth, respectively. A significant negative relationship was found between the variable Risk-taking ( $p=$ $0,026)$ and the dependent variable Business growth. No relationship could be found between the independent variable Competitive aggressiveness and the dependent variable Business growth.

The hypotheses that there is a positive relationship between the entrepreneurial orientation independent variables, i.e. Proactiveness $\left(\mathrm{H}^{4 \mathrm{~b}}\right)$; Autonomy $\left(\mathrm{H}^{1 \mathrm{~b}}\right)$ and Innovativeness $\left(\mathrm{H}^{2 \mathrm{~b}}\right)$, and the dependent variable Business growth, respectively, were therefore accepted. The hypotheses that there is a positive relationship between the independent variables Risk-taking $\left(\mathrm{H}^{3 \mathrm{~b}}\right)$ and Competitive aggressiveness $\left(\mathrm{H}^{5 \mathrm{~b}}\right)$ and Business growth were, however, not accepted.

\section{Conclusion and recommendations}

The objective of this study was to investigate the relationship between the entrepreneurial orientation of agribusinesses in South Africa and their perceived success. The results show that managers in the participating agribusinesses perceived the following entrepreneurial orientation factors as influencing the Business development and improvement i.e. Proactiveness, Risk-taking and Autonomy. Put differently, agribusinesses that are continuously monitoring market trends and future needs of customers; pursuing opportunities created by these trends and needs; improving existing products/services continually; having a strong inclination towards high risk projects and when confronted with uncertainty, typically adopts a bold posture to maximise the probability of exploiting opportunities; encouraging their employees to manage their own work without continual supervision and being allowed flexibility to be creative and try different methods to do their jobs, are more likely to experience an increase in organisational efficiency and effectiveness, improved image as well as increased job satisfaction and highly committed employees.
Similar to the findings of Lumpkin et al. (2010), positive relationships were also found to exist between the entrepreneurial orientation factors Proactiveness, Autonomy and Innovativeness, and the Business growth of the participating agribusinesses. In practice, this implies that the more agribusinesses are continuously monitoring market trends and future needs of customers; pursuing opportunities created by these trends and needs; improving existing products/services continually; encouraging their employees to manage their own work without continual supervision and being allowed flexibility to be creative and try different methods to do their jobs; introducing new products/services/processes on a regular basis; increasing the number of service/product offerings during the past few years and the extent to which these new products/services/processes have been dramatic within the past few years, the more likely it will lead to business growth in terms of increased turnover, profits and market share.

Competitive aggressiveness, consistent with the findings from Lumpkin and Dess (2001) and Lumpkin et al. (2010), showed no relationship with Business development and improvement or Business growth. In this regard, Lumpkin and Dess (2001:446) perhaps present an explanation and argue that Competitive aggressiveness may enhance a business' efforts to maintain a strong position relative to competitors (reactive behaviour), but this behaviour may not necessarily lead to higher performance. Surprisingly, a negative relationship is reported between the independent variable Risk-taking and the dependent variable Business growth. In part, this finding can be explained by the riskadverse culture of managers in the participating agribusinesses found to exist during a similar study (Lotz, 2009: 230). The reason for the positive relationship between Risk-taking and Business development and improvement, yet simultaneously showing a negative relationship with Business growth, is unclear. It is recommended that this finding be investigated with follow-up studies to explain the finding.

To enhance the entrepreneurial orientation in agribusiness, a number of recommendations are put forward. Firstly, because an entrepreneurial orientation has its roots in the strategy-making process, it is recommended that entrepreneurship becomes the strategic way of thinking (dominant logic) within agribusinesses. This can be done by specifically including the word "entrepreneurship" in the vision statement of the business, setting goals and developing strategies for entrepreneurship. The focus of the business then becomes opportunity identification, discovery 
of new sources of value, and product and process innovation that could lead to greater success.

Being proactive or the posture of anticipating and acting on future wants and needs in the marketplace is vital to the entrepreneurial orientation in businesses. Agribusinesses must therefore constantly monitor the external environment and, importantly, disseminate this information among all employees with the view of seeking new opportunities and ideas.

It is the task of management to create an environment in which workplace autonomy can be fostered. Furthermore, autonomy must actually be granted to employees to enable them to exploit new opportunities and ideas. In this regard, task objectives should be framed in such a way that they are clear but defined in broad terms to allow employees the freedom to pursue a number of different approaches to perform their tasks.

New opportunities and ideas need to culminate into new products/services/processes. Goals and objectives need to be set for innovation. This must include the type of innovation as well as the number of innovative products/ services/processes required. An integrative approach to the type of innovation is recommended and goals and objectives must be developed for both incremental innovations as well as radical innovations.

The adversity to risk-taking in agribusinesses must be addressed. Risk-taking behaviour needs to be encouraged in agribusinesses by articulating to employees that risk-taking behaviour is acceptable. Naturally, employees will be sceptical and it may be necessary to set boundaries for risktaking behaviour by explaining the types of risk-taking behaviour that will be acceptable. Agribusinesses must develop rules and procedures regarding risk-taking behaviour and identify areas where risk-taking would be acceptable as well as the level of risk that would be tolerated.

Finally, in today's dynamic and uncertain competitive environment, successful agribusinesses will be those in which entrepreneurial behaviour will be used to explore opportunities to build a foundation for future success.

\section{Limitations and suggestions for further research}

This study has attempted to make a contribution to the body of knowledge on the relationship between entrepreneurial orientation and the perceived success of South African agribusinesses. Although there is general consensus in the literature on the dimensions measuring entrepreneurial orientation, there is little consensus on the underlying dimensions of business success. Success may therefore depend upon the indicators used to assess success. More comprehensive research is therefore still needed to clarify the underlying dimensions of business success. Another limitation is that, when measuring success, this study relied entirely on the perceptions of the respondents. To close the gap between perception and reality, future research could be designed to collect actual data on business success such as turnover, profits and market share, for example.
The sampling method used to determine the agribusiness study population was a non-probability sample. Furthermore, only agribusinesses previously known as agricultural co-operatives were considered for this study. The findings can therefore not be considered to be representative of all agribusinesses in South Africa. Care should therefore be exercised in the interpretation and utilisation of the results, and the findings of the study cannot be generalised to all agribusinesses. In other words, the typical agribusiness could be underrepresented in the sample. The low response rate from some of the agribusinesses may also skew the findings towards those agribusinesses with a higher response rate.

Finally, the exploratory factor analysis of the measuring instrument assessing the entrepreneurial orientation and perceived success of agribusinesses provides some evidence of construct validity and reliability. Further research is, however, needed before the measuring instrument can be utilised to diagnose these issues in corporate businesses.

\section{References}

Anderson, P. \& Tushman, M.L. 2004. 'Managing through cycles of technological change'. In Tushman, M.L. \& Anderson, P. (eds.). Managing strategic innovation and change. $2^{\text {nd }}$ Edition. New York, NY: Oxford University Press.

Antoncic, B. \& Hisrich, R.D. 2001. 'Intrapreneurship: Construct refinement and cross-cultural validation', Journal of Business Venturing, 16(5):495-527.

Bagozzi, R.P. 1994. Principles of marketing research. Cambridge: Blackwell.

Baran, D. \& Velickaité, R. 2008. 'Building the theoretical framework of entrepreneurship'. Paper delivered at the Fifth International Scientific Conference, Business and Management held in Vilnius, Lithuania, 16-17 May.

Bessant, J. 2003. High-involvement innovation. West Sussex: John Wiley \& Sons Ltd.

Bhardwaj, B.R., Agrawal, S. \& Momaya, K. 2007. 'Corporate entrepreneurship model: Source of competitiveness', IIMB Management Review, 19(2):131145 .

Brock, D.M. 2003. 'Autonomy of individuals and organizations: Towards a strategy research agenda', International Journal of Business and Economics, 2(1):5773.

Bryman, A. \& Bell, E. 2007. Business research methods. $2^{\text {nd }}$ Edition. New York, NY: Oxford University Press.

Bulut, C. \& Alpkan, L. 2006. 'Behavioural consequences of an entrepreneurial climate within large organisations: An integrative proposed model', The South East European Journal of Economics and Business, 1(2):64-70. 
Burns, P. 2008. Corporate entrepreneurship: Building the entrepreneurial organization. $2^{\text {nd }}$ Edition. Hampshire: Palgrave Macmillan.

Casillas, J.C. \& Moreno, A.M. 2010. 'The relationship between entrepreneurial orientation and growth: The moderating role of family involvement', Entrepreneurship \& Regional Development, 22(3-4):265-291.

Chang, S.C., Lin, R.J., Chang, F.J. \& Chen, R.H. 2007. 'Achieving manufacturing flexibility through entrepreneurial orientation', Industrial Management \& Data Systems, 107(7):997-1017.

Chen, J., Zhu, Z. \& Anquan, W. 2005. 'A system model for corporate entrepreneurship', International Journal of Manpower, 26(6):529-543.

Christensen, C.M., Johnson, M.W. \& Rigby, D.K. 2002. 'Foundations for growth: How to identify and build disruptive new businesses', Sloan Management Review, 43(13):22-31.

Collis, D.J. \& Montgomery, C.A. 2005. Corporate strategy: A resource-based approach. New York, NY: McGraw-Hill Irwin.

Cooper, J.R. 1998. 'A multidimensional approach to the adoption of innovation', Management Decision, 36(8):493502.

Covin, J.G., Green, K.M. \& Slevin, D.P. 2006. 'Strategic process effects on the entrepreneurial orientation: Sales growth rate relationship', Entrepreneurship Theory and Practice, 30(1):57-81.

Covin, J.G. \& Lumpkin, G.T. 2011. 'Entrepreneurial orientation theory and research: Reflections on a needed construct', Entrepreneurship Theory and Practice, 35(5):855-872.

Covin, J.G. \& Miles, M.P. 1999. 'Corporate entrepreneurship and the pursuit of competitive advantage', Entrepreneurship Theory and Practice, 23(3):47-63.

Covin, J.G. \& Slevin, D.P. 1989. 'Strategic management of small firms in hostile and benign environments', Strategic Management Journal, 10(1):75-87.

Covin, J.G. \& Slevin, D.P. 1991. 'A conceptual model of entrepreneurship as firm behaviour', Entrepreneurship Theory and Practice, 16(1):7-25.

David, F.R. 2007. Strategic management: Concepts \& cases. $11^{\text {th }}$ Edition. Upper Saddle River, NJ: Prentice Hall.

Davis, D. 2005. Business research for decision making. $6^{\text {th }}$ Edition. Belmont, CA: Thomson Learning.

Dess, G.G., Ireland, R.D., Zahra, S.A., Floyd, S.W., Janney, J.J. \& Lane, P.J. 2003. 'Emerging issues in corporate entrepreneurship', Journal of Management, 29(3):351-378.
Dess, G.G. \& Lumpkin, G.T. 2005. 'The role of entrepreneurial orientation in stimulating effective corporate entrepreneurship', Academy of Management Executive, 19(1):147-156.

Dess, G., Lumpkin, G. \& Covin, J.G. 1997. 'Entrepreneurial strategy making and firm performance: Tests of contingency and configurational models', Strategic Management Journal, 18(9):677-695.

Dewett, T. 2004. 'Employee creativity and the role of risk', European Journal of Innovation Management, 7(4):257266.

Doyer, O.T., D’Haese, M.F.C., Kirsten, J.F. \& Van Rooyen, C.J. 2007. 'Strategic focus areas and emerging trade arrangements in the South African agricultural industry since the demise of the marketing boards', Agrekon, 46(4):494-513.

Dreyer, A. 2006. 'Strategic innovation: A new perspective on strategic management', Handbook of business strategy, 7(1):143-147.

Ellis, S.M. \& Steyn, H.S. 2003. 'Practical significance versus or in combination with statistical significance', Management Dynamics, 12(4):51-53.

Field, A. 2009. Discovering statistics using SPSS. $3^{\text {rd }}$ Edition. London: Sage Publications.

Frank, H., Kessler, H. \& Fink, M. 2010. 'Entrepreneurial orientation and business performance - a replication study', Schmalenbach Business Review, 62(2):175-198.

George, B.A. \& Marino, L. 2011. 'The epistemology of entrepreneurial orientation: Conceptual formation, modelling, and operationalisation', Entrepreneurship Theory and Practice, 35(5):989-1024.

Gürbüz, G. \& Aykol, S. 2009. 'Entrepreneurial management, entrepreneurial orientation and Turkish small firm growth', Management Research News, 32(4):321-336.

Hayton, J.C. 2005. 'Promoting corporate entrepreneurship through human resource management practices: A review of empirical research', Human Resource Management Review, 15(1):21-41.

Heinonen, J. \& Toivonen, J. 2008. 'Corporate entrepreneurs or silent followers?', Leadership and Organizational Development Journal, 29(7):583-599.

Hill, M.E. 2003. 'The development of an instrument to measure intrapreneurship: Entrepreneurship within the corporate setting'. Unpublished doctoral thesis, Rhodes University, Grahamstown.

Hornsby, J.S., Kuratko, D.F. \& Zahra, S.A. 2002 'Middle managers' perception of the internal environment for corporate entrepreneurship: Assessing a measurement scale', Journal of Business Venturing, 17(3):253-273. 
Ireland, R.D., Hitt, M.A. \& Sirmon, D.G. 2003. 'A model of strategic entrepreneurship: The construct and its dimensions', Journal of Management, 29(6):963-989.

Ireland, R.D. \& Webb, J.W. 2009. 'Crossing the great divide of strategic entrepreneurship: Transitioning between exploration and exploitation', Business Horizons, 52(5):469479 .

Jacobs, F.R., Chase, R.B. \& Aquilano, N.J. 2009. Operations \& supply management. $12^{\text {th }}$ Edition. Boston, MA: McGraw-Hill Irwin.

Johnson, D. 2001. 'What is innovation and entrepreneurship? Lessons for larger organisations', Industrial and Commercial Training, 33(4):135-140.

Kemelgor, B.H. 2002. 'A comparative analysis of corporate entrepreneurial orientation between selected firms in the Netherlands and the USA', Entrepreneurship and Regional Development, 14(1):67-87.

Kent, R. 2007. Marketing research: Approaches, methods, and applications in Europe. London: Thomson Learning.

Kleinschmidt, E.J. \& Cooper, R.G. 1991. 'The impact of product innovativeness on performance', Journal of Product Innovation Management, 8(4):240-251.

Knight, G.A. 1997. 'Cross-cultural reliability of a scale to measure firm entrepreneurial orientation', Journal of Business Venturing, 12(3):213-225.

Kreitner, R. \& Kinicki, A. 2008. Organizational behavior. $8^{\text {th }}$ Edition. Boston, MA: McGraw-Hill.

Kropp, F., Lindsay, N.J. \& Shoham, A. 2008. 'Entrepreneurial orientation and international entrepreneurial business venture start-up', International Journal of Entrepreneurial Behaviour \& Research, 14(2):102-117.

Kuratko, D.F. \& Audretsch, D.B. 2009. 'Strategic entrepreneurship: Exploring different perspectives of an emerging concept', Entrepreneurship Theory and Practice, 33(1):1-17.

Lambing, P.A. \& Kuehl, C.R. 2007. Entrepreneurship. $4^{\text {th }}$ Edition. Upper Saddle River, NJ: Pearson Prentice Hall.

Lassen, A.H., Gertsen, F. \& Riis, J.O. 2006. 'The nexus of corporate entrepreneurship and radical innovation', Creativity and Innovation Management, 15(4):359-372.

Lee, L.T.S. \& Sukoco, B.M. 2007. 'The effects of entrepreneurial orientation and knowledge management on organizational effectiveness in Taiwan: The modelling role of social capital', International Journal of Management, 24(3):549-572.
Leedy, P.D. \& Ormrod, J.E. 2005. Practical Research: planning and design. $8^{\text {th }}$ Edition. Upper Saddle River, NJ : Prentice Hall.

Lotz, H.M. 2009. 'An assessment of the determinants of corporate entrepreneurship in agricultural businesses: An integrated framework'. Unpublished doctoral thesis, NorthWest University, Potchefstroom.

Lumpkin, G.T., Brigham, K.H. \& Moss, T.W. 2010. 'Longterm orientation: Implications for the entrepreneurial orientation and performance of family businesses', Entrepreneurship \& Regional Development, 22(3-4):241264.

Lumpkin, G.T., Cogliser, C.C. \& Schneider, D.R. 2009. 'Understanding and measuring autonomy: An entrepreneurial orientation perspective', Entrepreneurship Theory and Practice, 33(1):47-69.

Lumpkin, G.T. \& Dess, G.G. 1996. 'Clarifying the entrepreneurial orientation construct and linking it to performance', Academy of Management Review, 21(1):135172.

Lumpkin, G.T. \& Dess, G.G. 2001. 'Linking two dimensions of entrepreneurial orientation to firm performance: The moderating role of environment and industry life cycle', Journal of Business Venturing, 16(5):429-451.

Madsen, E.L. 2007. 'The significance of sustained entrepreneurial orientation on performance of firms: A longitudinal analysis', Entrepreneurship \& Regional Development, 19(2):185-204.

McBeth, E.W. \& Rimac, T. 2004. 'The age of entrepreneurial turbulence: Creating sustainable advantage for individuals, organizations, and societies in the new century', Esade MBA Business Review, 2:17-22.

McFadzean, E., O’Loughlin, A. \& Shaw, E. 2005. 'Corporate entrepreneurship and innovation Part 1: The missing link', European Journal of Innovation Management, 8(3):350-372.

McGrath, R.G. \& MacMillan, I. 2000. The entrepreneurial mindset. Boston, MA: Harvard Business School Publishing.

Miller, D. 1983. 'The correlates of entrepreneurship in three types of firms', Management Science, 29(7):770-791.

Miller, D. 2011 'Miller (1983) revisited: A reflection on EO research and some suggestions for the future', Entrepreneurship Theory and Practice, 35(5):873-894.

Morena, A.M. \& Casillas, J.C. 2008. 'Entrepreneurial orientation and growth of SMEs: A causal model', Entrepreneurship Theory and Practice, 32(3):507-528.

Morris, M.H., Kuratko, D.F. \& Covin, J.G. 2008. Corporate entrepreneurs and innovation. $2^{\text {nd }}$ Edition. Mason, OH: South-Western. 
Mullins, J.W. \& Forlani, D. 2005. 'Missing the boat or sinking the boat: A study of new venture decision making', Journal of Business Venturing, 20(1):47-69.

Mumford, M.D., Scott, G.M., Gaddis, B. \& Stange, J.M. 2002. 'Leading creative people: Orchestrating expertise and relationships', The Leadership Quarterly, 13(6):705-750.

Nieuwenhuizen, C. 2003. 'The nature and development of entrepreneurship'. In Niemand, G., Hough. J. \& Niewenhuizen, C. (eds.). Entrepreneurship: A South African perspective. Pretoria: Van Schaik Publishers, pp. 3-26.

Oosthuizen, J.H. 2006. 'An integrated framework to improve the entrepreneurial climate in South African mining industry'. Unpublished doctoral thesis, North-West University, Potchefstroom.

Ortmann, G.F. \& King, R.P. 2007. 'Agricultural cooperatives 1: History, theory and problems', Agrekon, 46(1):40-68.

PASW STATISTICS. 2010. PASW 18 for Windows, Release 18. Copyright $\odot$ by SPSS Inc. Chicago, Il: SPSS.

Ramachandran, K., Devaranjan, T.T. \& Ray, S. 2006. 'Corporate entrepreneurship: How?' Vikalpa: The Journal for Decision-makers, 31(1):85-97.

Rauch, A. \& Frese, M. 2007. 'Let's put the person back into entrepreneurship research: A meta-analysis on the relationship between business owners' personality traits, business creation, and success', European Journal of Work and Organizational Psychology, 16(4):353-385.

Rauch, A., Wiklund, J., Frese, M. \& Lumpkin, G.T. 2004. 'Entrepreneurial orientation and business performance: Cumulative empirical evidence'. Frontiers of Entrepreneurship Research 2004: Proceedings of the twenty-fourth annual Entrepreneurship Research Conference, pp.164-177.

Rauch, A., Wiklund, J., Lumpkin, G.T. \& Frese, M. 2009. 'Entrepreneurial orientation and business performance: An assessment of past research and suggestions for the future', Entrepreneurship Theory and Practice, 33(3):761-787.

Richard, O.C., Wu, P. \& Chadwick, K. 2009. 'The impact of entrepreneurial orientation on firm performance: The role of CEO position tenure and industry tenure', The International Journal of Human Resource Management, 20(5):1078-1095.

Scheepers, M.J., Hough, J. \& Bloom, J.Z. 2008. 'Nurturing the corporate entrepreneurship capability', Southern African Business Review, 12(3):50-75.

Schilling, M.A. 2005. Strategic management of technological innovation. Boston, MA: McGraw-Hill Irwin.

Shane, S., Locke, E.A. \& Collins, C.J. 2003. 'Entrepreneurial motivation', Human Resource Management Review, 13(2):257-279.
STATSOFT, INC. 2010. Statistica (Data Analysis Software System). Release 10. [online] URL:www.statsoft.com.

Stevens, J.P. 1992. Applied multivariate statistics for the social sciences. $2^{\text {nd }}$ Edition. Hillsdale, NJ: Erlbaum.

Subramanian, A. \& Nilakanta, S. 1996. 'Organizational innovativeness: Exploring the relationship between organizational determinants of innovation, types of innovations, and measures of organizational performance', Omega, 24(6):631-647.

Timmons, J.A. \& Spinelli, S. 2009. New venture creation: Entrepreneurship for the $21^{\text {st }}$ century. $8^{\text {th }}$ Edition. Boston, MA: Irwin/McGraw-Hill.

Van der Post, W.Z. 1997. 'The relationship between organisational culture and financial performance among industrial organisations listed on the JSE'. Unpublished DBA-dissertation, University of Stellenbosch, Graduate Business School Bellville South Africa.

Von Stamm, B. 2008. Managing innovation, design and creativity. $2^{\text {nd }}$ Edition. West Sussex: John Wiley \& Sons.

Wang, C.L. 2008. 'Entrepreneurial orientation, learning orientation, and firm performance', Entrepreneurship Theory and Practice, 32(4):635-656.

Wiklund, J. 1999. 'The sustainability of entrepreneurial orientation - performance relationship', Entrepreneurship Theory and Practice, 24(1):37-48.

Wiklund, J. \& Shepherd, D. 2003. 'Knowledge-based resources, entrepreneurial orientation, and the performance of small and medium-sized businesses', Strategic Management Journal, 24(13):1307-1314.

Wiklund, J. \& Shepherd, D. 2005. 'Entrepreneurial orientation and small business performance: A configurational approach', Journal of Business Venturing, 20(1):71-91.

Wolpert, J.D. 2002. 'Breaking out of the innovation box', Harvard Business Review, 80(8):77-83.

Yamada, K. \& Eshima, Y. 2009. 'Impact of entrepreneurial orientation: Longitudinal analysis of small technology firms in Japan', Academy of Management Proceedings.

Zahra, S.A., Jennings, D.F. \& Kuratko, D.F. 1999. 'The antecedents and consequences of firm-level entrepreneurship: The state of the field', Entrepreneurship Theory and Practice, 24(2):45-65.

Zikmund, W.G. \& Babin, B.J. 2007. Exploring marketing research. $9^{\text {th }}$ Edition. Mason, $\mathrm{OH}$ : Thomson Learning. 
Appendix 1: Items measuring the dependent variable

\begin{tabular}{|c|c|}
\hline Item & Statement \\
\hline \multicolumn{2}{|r|}{ BUSS DEVELOPMENT AND IMPROVEMENT } \\
\hline Success7 & In our business, employees are viewed as the most valuable asset of the business. \\
\hline Success8 & Our employees are highly committed to our business. \\
\hline Success9 & The morale (job satisfaction) of our employees has improved over the past few years. \\
\hline Success 10 & $\begin{array}{l}\text { The image (stature) of our business, relative to our competitors, has grown over the past few } \\
\text { years. }\end{array}$ \\
\hline Success5 & The effectiveness (doing the right things) of our business has improved over the past few years. \\
\hline Success 11 & $\begin{array}{l}\text { During difficult economic periods, investments in research and development/ innovative projects } \\
\text { continue and no significant financial cuts are made. }\end{array}$ \\
\hline Success6 & The efficiency (doing things right) of our business has improved over the past few years. \\
\hline \multicolumn{2}{|r|}{ BUSINESS GROWTH } \\
\hline Success2 & Our business has experienced growth in profits over the past few years. \\
\hline Success1 & Our business has experienced growth in turnover over the past few years. \\
\hline Success3 & Our business has experienced growth in market share over the past few years. \\
\hline Success4 & The competitive position of our business has improved over the past few years. \\
\hline
\end{tabular}

\section{Appendix 1: Items measuring the independent variables}

\begin{tabular}{|c|c|}
\hline Item & Statement \\
\hline \multicolumn{2}{|r|}{ AUTONOMY } \\
\hline Autonomy 01 & I have enough autonomy in my job without continual supervision to do my work. \\
\hline Autonomy 02 & Our business allows me to be creative and try different methods to do my job. \\
\hline Autonomy 03 & $\begin{array}{l}\text { Employees in our business are allowed to make decisions without going through elaborate } \\
\text { justification and approval procedures. }\end{array}$ \\
\hline Autonomy 04 & $\begin{array}{l}\text { Employees in our business are encouraged to manage their own work and have flexibility to } \\
\text { resolve problems. }\end{array}$ \\
\hline Autonomy 05 & $\begin{array}{l}\text { I seldom have to follow the same work methods or steps while performing my major tasks from } \\
\text { day to day. }\end{array}$ \\
\hline \multicolumn{2}{|r|}{ INNOVATIVENESS } \\
\hline Innovativeness 01 & Our business regularly introduces new services/products/processes. \\
\hline Innovativeness 02 & Our business places a strong emphasis on new and innovative products/ services/processes. \\
\hline Innovativeness 03 & Our business has increased the number of services/products offered during the past two years. \\
\hline Innovativeness 04 & Our business is continually pursuing new opportunities. \\
\hline Innovativeness 05 & $\begin{array}{l}\text { Over the past few years, changes in our processes, services and product lines have been quite } \\
\text { dramatic. }\end{array}$ \\
\hline Innovativeness 06 & $\begin{array}{l}\text { In our business there is a strong relationship between the number of new ideas generated and the } \\
\text { number of new ideas successfully implemented. }\end{array}$ \\
\hline Innovativeness 07 & $\begin{array}{l}\text { Our business places a strong emphasis on continuous improvement in products/service } \\
\text { delivery/processes. }\end{array}$ \\
\hline Innovativeness 08 & $\begin{array}{l}\text { Our business has a widely held belief that innovation is an absolute necessity for the business' } \\
\text { future. }\end{array}$ \\
\hline Innovativeness 09 & $\begin{array}{l}\text { Our leaders seek to maximise value from opportunities without constraint to existing models, } \\
\text { structures or resources. }\end{array}$ \\
\hline \multicolumn{2}{|r|}{ RISK TAKING } \\
\hline Risk-taking 01 & $\begin{array}{l}\text { When confronted with uncertain decisions, our business typically adopts a bold posture in order } \\
\text { to maximise the probability of exploiting opportunities. }\end{array}$ \\
\hline Risk-taking 02 & In general, our business has a strong inclination towards high-risk projects. \\
\hline
\end{tabular}




\begin{tabular}{|l|l|}
\hline Risk-taking 03 & $\begin{array}{l}\text { Owing to the environment, our business believes that bold, wide-ranging acts are necessary to } \\
\text { achieve the business' objectives. }\end{array}$ \\
\hline Risk-taking 04 & Employees are often encouraged to take calculated risks concerning new ideas. \\
\hline Risk-taking 05 & The term 'risk-taker' is considered a positive attribute for employees in our business. \\
\hline & \multicolumn{1}{|c|}{ PROACTIVENESS } \\
\hline Proactiveness 01 & Our business is very often the first to introduce new products/services/ processes. \\
\hline Proactiveness 02 & Our business typically initiates actions that competitors respond to. \\
\hline Proactiveness 03 & Our business continuously seeks out new products/processes/services. \\
\hline Proactiveness 04 & Our business continuously monitors market trends and identifies future needs of customers. \\
\hline
\end{tabular}

